\title{
PENGARUH PENEMPATAN DAN LINGKUNGAN KERJA TERHADAP KINERJA PEGAWAI PADA BADAN AMIL ZAKAT NASIONAL BAZNAS (BAZIS) PROVINSI DKI JAKARTA
}

\author{
Bachtiar Arifudin Husain \\ Universitas Pamulang, Tangerang, Banten, Indonesia \\ dosen01773@unpam.ac.id
}

\begin{abstract}
Abstrak
Tujuan penelitian ini adalah untuk mengetahui pengaruh penempatan dan lingkungan kerja terhadap kinerja pegawai pada Badan Amil Zakat Nasional BAZNAS (BAZIS) Provinsi DKI Jakarta baik secara parsial maupun secara simultan. Metode yang digunakan adalah kuantitatif. Teknik pengambilan sampel menggunakan sampling jenuh dan diperoleh sampel dalam penelitian ini berjumlah 82 responden. Analisis data menggunakan uji validitas, uji reliabilitas, uji asumsi klasik, analisis regresi, analisis koefisien korelasi, analisis koefisien determinasi dan uji hipotesis. Hasil penelitian ini adalah penempatan dan lingkungan kerja berpengaruh signifikan terhadap kinerja pegawai dengan persamaan regresi $Y=8,835+0,482 X_{1}+0,300 X_{2}$. Nilai korelasi sebesar 0,754 artinya variabel bebas dengan variabel terikat memiliki tingkat hubungan yang kuat. Nilai koefisien determinasi sebesar $56,8 \%$ sedangkan sisanya sebesar $43,2 \%$ dipengaruhi faktor lain. Uji hipotesis diperoleh nilai $F_{\text {hitung }}>F_{\text {tabel }}$ atau $(51,977>2,720)$. Dengan demikian $\mathrm{H}_{\mathrm{o}}$ ditolak dan $\mathrm{H}_{\mathrm{a}}$ diterima. Artinya terdapat pengaruh signifikan secara simultan penempatan dan lingkungan kerja terhadap kinerja pegawai.
\end{abstract}

Kata Kunci: Penempatan, Lingkungan Kerja, Kinerja Pegawai

\section{Abstract}

The purpose of this study was to determine the effect of placement and work environment on employee performance at the National Amil Zakat Agency (BAZIS) of DKI Jakarta Province, either partially or simultaneously. The method used is quantitative. The sampling technique used was saturated sampling and the sample obtained in this study amounted to 82 respondents. Data analysis used validity test, reliability test, classical assumption test, regression analysis, correlation coefficient analysis, coefficient of determination analysis and hypothesis testing. The result of this study is that placement and work environment have a significant effect on employee performance with the regression equation $Y=8.835+0.482 X 1+0.300 X 2$. The correlation value of 0.754 means that the independent variable and the dependent variable have a strong level of relationship. The value of the coefficient of determination is $56.8 \%$ while the remaining $43.2 \%$ is influenced by other factors. Hypothesis test obtained value Fcount > Ftable or $(51,977>2,720)$. Thus Ho is rejected and Ha is accepted. This means that there is a simultaneous significant effect of placement and work environment on employee performance.

Keywords: Placement, Work Environment, Employee Performance

\section{PENDAHULUAN}

Dalam mencapai tujuannya, setiap organisasi sangat memerlukan manajemen yang baik. Penerapan manajemen yang baik sangatlah penting dalam menyaring sumber daya yang benar - benar memenuhi kriteria yang dibutuhkan oleh organisasi, karena jika salah dalam memilih sumber daya manusia yang dibutuhkan, maka dapat berakibat buruk bagi kelangsungan organisasi. Sebaliknya, penerapan sumber daya manusia yang tepat dalam organisasi akan menghasilkan peningkatan kemampuan sebuah organisasi untuk memperoleh dan mempertahankan orang - orang terbaik pada bidangnya. Mulai dari perencanaan melalui aktivitas rekruitmen dan seleksi yang berkualitas menunjukkan orangorang yang terbaik untuk jabatan yang tersedia dan memastikan bahwa mereka 
ditempatkan pada posisi yang tepat. Evaluasi kinerja juga akan mengembangkan individu yang menuntut keahlian, pengetahuan, dan sikap yang berbeda dari yang mereka miliki sekarang ini.

Widodo (2015: 2) mengemukakan bahwa Manajemen Sumber Daya Manusia adalah suatu proses yang mencakup evaluasi terhadap kebutuhan SDM, mendapatkan orang - orang untuk memenuhi kebutuhan itu dan mengoptimalkan pendayagunaan sumber daya dengan cara memberikan penugasan yang tepat, agar sesuai dengan kebutuhan dan tujuan organisasi di mana SDM itu berada.

Badan Amil Zakat Nasional BAZNAS (BAZIS) Provinsi DKI Jakarta merupakan suatu badan yang menangani segala proses pengumpulan, pendistribusian dan pendayagunaan zakat di tingkat provinsi. BAZNAS (BAZIS) Provinsi DKI Jakarta dibentuk berdasarkan pada UU No 23 Tahun 2011 tentang Pengelolaan Zakat yang mengamanatkan pembentukan BAZNAS (Badan Amil Zakat Nasional) oleh pemerintah di tingkat nasional, provinsi dan kabupaten/kota. BAZNAS (BAZIS) Provinsi DKI Jakarta menggantikan posisi peran BAZIS DKI Jakarta yang telah berkiprah sejak tahun 1968. BAZIS (Badan Amil Zakat Infaq Sadaqah) Provinsi DKI Jakarta berdiri atas saran sebelas tokoh ulama nasional yaitu Prof Buya Hamka, Buya H.A. Malik Ahmad, KH. Ahmad Azhari, KH. M. Sjukri Ghazali, KH. Taufiqurrahman, H.Moh Sodry, KH. Saleh Suaidy, M. Ali Al Hamidy, Mukhtar Luthfy, Abdul Kadir, dan KH. MA. Zawawy yang berkumpul di Jakarta pada 24 September 1968.

\section{Kehadiran BAZNAS (BAZIS)}

Provinsi DKI Jakarta diharapkan dapat menyadarkan masyarakat Indonesia mengenai keutamaan dari zakat. Mengingat mayoritas masyarakat Indonesia adalah muslim dan melalui berbagai program yang diadakan oleh BAZNAS (BAZIS) Provinsi DKI Jakarta, diharapkan mampu meningkatkan kesejahteraan hidup umat terutama dari golongan yang menerima zakat, sehingga mereka bisa hidup dengan layak. Oleh karena itu, demi terwujudnya program program kesejahteraan bagi masyarakat Indonesia khususnya Provinsi DKI Jakarta, BAZNAS (BAZIS) Provinsi DKI Jakarta harus mempunyai sumber daya manusia yang memang sesuai di bidangnya untuk menunjang agar semua program berjalan dengan baik sebagaimana mestinya.

Penempatan kerja merupakan salah satu faktor penting dalam menilai kinerja pegawai. Berasal dari istilah "The Right Man On The Right Place" yang berarti bahwa dalam menempatkan seorang pegawai sesungguhnya harus sesuai dengan kemampuan atau keahliannya. Maka, hendaknya suatu organisasi dapat menempatkan pegawai sesuai dengan kriterianya.

Menurut Bangun (2012: 159) penempatan (placement) berkaitan dengan penyesuaian kemampuan dan bakat seseorang dengan pekerjaan yang akan dikerjakannya.

Berdasarkan observasi awal, peneliti melihat bahwa penempatan pegawai BAZNAS (BAZIS) Provinsi DKI Jakarta masih belum maksimal. Hal ini disinyalir karena dalam prosesnya, setiap pegawai BAZNAS (BAZIS) Provinsi DKI Jakarta sering dipindah posisikan dari suatu jabatan/posisi ke posisi yang baru pada bagian tertentu dan wilayah tertentu tanpa memandang latar belakang pendidikan yang telah ditempuh oleh pegawai sehingga kurangnya pengetahuan dapat menyebabkan pencapaian hasil kerja yang kurang maksimal.

Berkaitan dengan hal tersebut, seperti data tingkat pendidikan pegawai pada BAZNAS (BAZIS) Provinsi DKI Jakarta dibawah ini, membutuhkan suatu proses penempatan kerja yang tepat agar pegawai tetap dapat melaksanakan kegiatannya dengan baik dan dapat mencapai target kinerja pegawai pada 
bidang kerjanya sehingga tujuan organisasi dapat tercapai.

Selain penempatan kerja, lingkungan kerja juga dapat mempengaruhi peningkatan kinerja pegawai. Menurut Kadarisman (2012: 300) lingkungan kerja adalah keseluruhan sarana dan prasarana yang ada di sekitar pegawai yang sedang melakukan pekerjaan yang dapat mempengaruhi pelaksanaan pekerjaan itu sendiri. Dengan memperhatikan lingkungan kerja yang baik ataumenciptakan kondisi kerja yang mampu memberikan motivasi untuk bekerja, maka akan membawa pengaruh terhadap kegairahan atau semangat karyawan bekerja. Selain itu, hubungan dengan rekan kerja yang harmonis, tersedianya fasilitas kerja yang memadai, penerangan/cahaya yang cukup di ruangan kerja, sirkulasi udara yang bersih, tidak adanya bunyi yang tidak dikehendaki dan terjaminnya keamanan seperti adanya satpam yang bisa menjaga di lingkungan gedung diharapkan dapat menunjang proses dalam bekerja sehingga dapat meningkatkan kinerja dari pegawai.

Mengingat pentingnya lingkungan kerja bagi pegawai, maka organisasi diharapkan dapat menciptakan lingkungan kerja yang baik. Lingkungan kerja yang baik dapat menambah kenyamanan dan konsentrasi karyawan sehingga mampu meningkatkan kinerja yang dimiliki. Sedangkan lingkungan kerja yang kurang nyaman bagi pegawai dan dianggap tidak memadai akan membuat pegawai merasa tidak betah dan tidak bersemangat dalam menjalankan kewajibannya dan menyelesaikan pekerjaan - pekerjaan yang diberikan yang akan dapat menimbulkan penurunan kinerja pegawai.

Kinerja (performance) adalah hasil pekerjaan yang dicapai seseorang berdasarkan persyaratan pekerjaan (jobrequirement). Moeheriono (2012: 95) mengatakan bahwa kinerja atau performance merupakan gambaran mengenai tingkat pencapaian pelaksanaan suatu program kegiatan atau kebijakan dalam mewujudkan sasaran, tujuan, visi dan misi organisasi yang dituangkan melalui perencanaan strategis dari suatu organisasi. Menurut Hasibuan (2013: 31) mengemukakan bahwa kinerja sebagai prestasi kerja yang merupakan upaya membandingkan prestasi aktual karyawan dengan prestasi kerja yang diharapkan darinya. Untuk menentukan apakah suatu pekerjaan bisa dikerjakan dengan baik maka uraian pekerjaan akan sangat membantu dalam menentukan sasaran pekerjaannya.

Atas dasar berbagai permasalahan dan uraian yang ada di atas, maka peneliti ingin melakukan penelitian dengan judul "Pengaruh Penempatan dan Lingkungan Kerja terhadap Kinerja Pegawai pada Badan Amil Zakat Nasional BAZNAS (BAZIS) Provinsi DKI Jakarta".

\section{TINJAUAN PUSTAKA}

\section{Penempatan Kerja}

Menurut Yuniarsih dan Suwatno (2013: 116) penempatan pegawai adalah suatu proses untuk mencocokan dan membandingkan kualifikasi yang dimiliki oleh pegawai dengan kebutuhan dan persyaratan dari suatu jabatan atau pekerjaan di organisasi, sehingga the right man on the rightjob dapat tercapai.

Menurut Bangun (2012: 159) penempatan (placement) berkaitan dengan penyesuaian kemampuan dan bakat seseorang dengan pekerjaanyang akan dikerjakannya. Seseorang diberikan pekerjaan sesuai dengan pengetahuan, keterampilan, dan kemampuan yang dimiliki sesuai dengan persyaratan pekerjaan. Ketidaktelitian dalam hal ini bisa berakibat pada kurangnya semangat kerja yang berdampak pada rendahnya prestasi kerja.

Selanjutnya menurut Nurjaman (2014: 152) penempatan (placement) merupakan penugasan (assignment) atau penugasan kembali (reassignment) kepada seorang pegawai pada sebuah 
jabatan baru yang sebagian besar keputusan penempatan diambil oleh atasan langsung pegawai yang bersangkutan.

Dari beberapa teori diatas dapat disimpulkan bahwa penempatan kerja adalah suatu proses untuk menempatkan pegawai dari satu jabatan ke jabatan yang baru atau ke suatu jabatan yang berbeda. Supaya pegawai memiliki semangat dalam bekerja, berdisiplin tinggi dan bersikap loyal serta mampu mencapai target yang diharapkan dalam menunjang tujuan organisasi maka fungsi penempatan harus dilaksanakan dengan sebaik- baiknya.

\section{Lingkungan Kerja}

Lingkungan kerja yang kondusif dapat meningkatkan kinerja pegawai dan sebaliknya, lingkungan kerja yang tidak memadai akan dapat menurunkan kinerja pegawai. Oleh karena itu, hendaknya diusahakan agar lingkungan kerja harus baik dan kondusif karena lingkungan kerja yang baik dan kondusif menjadikan karyawan merasa betah berada di ruangan dan merasa senang serta bersemangat untuk melaksanakan pekerjaannya sehingga kepuasan kerja akan terbentuk dan dari kepuasan kerja karyawan tersebut maka kinerja karyawan juga akanmeningkat.

Menurut Nitiseminoto (2012: 183) lingkungan kerja adalah segala sesuatu yang ada disekitar para pekerja yang dapat mempengaruhi dirinya dalam menjalankan tugas - tugas yang telah dibebankan kepadanya.

Menurut Sedarmayanti (2011: 2) yang dimaksud dengan lingkungan kerja adalah keseluruhan alat perkakas dan bahan yang dihadapi oleh seseorang, lingkungan sekitarnya dimana seseorang bekerja, metode kerjanya, serta pengaturan kerjanya baik sebagai perseorangan maupun sebagai kelompok. Secara garis besar, jenis lingkungan kerja terbagi menjadi dua yaitu lingkungan kerja fisik dan lingkungan kerja non fisik.

Kadarisman (2012: 300) juga menyatakan bahwa lingkungan kerja adalah keseluruhan sarana dan prasarana yang ada di sekitar pegawai yang sedang melakukan pekerjaan yang dapat mempengaruhi pelaksanaan pekerjaan itu sendiri.

Dengan demikian, dapat disimpulkan bahwa lingkungan kerja adalah keseluruhan dari sarana prasarana kerja yang ada disekitar pegawai yang dapat digunakan untuk menunjang pekerjaan pegawai dalam mencapai tujuan organisasi. Walaupun lingkungan kerja merupakan faktor penting serta dapat mempengaruhi kinerja pegawai, tetapi masih banyak perusahaan yang kurang memperhatikan kondisi lingkungan kerja disekitarnya.

3. Kinerja

Sedarmayanti (2011: 260) mengungkapkan bahwa kinerja merupakan terjemahan dari performance yang berarti hasil kerja seorang pekerja, sebuah proses manajemen atau suatu organisasi secara keseluruhan, dimana hasil kerja tersebut harus dapat ditunjukkan buktinya secara konkrit dan dapat diukur (dibandingkan dengan standaryang telah ditentukan).

Menurut Bangun (2012: 231) kinerja (performance) adalah hasil pekerjaan yang dicapai seseorang berdasarkan persyaratan - persyaratan pekerjaan (Job Requirement).

Selanjutnya menurut Mangkunegara (2013: 67) kinerja diartikan sebagai hasil kerja secara kualitas dan kuantitas yang dicapai oleh seorang pegawai dalam melaksanakan tugasnya sesuai dengan tanggung jawab yang diberikan kepadanya.

Berdasarkan beberapa definisi di atas dapat disimpulkan bahwa kinerja pegawai adalah hasil kerja yang dicapai oleh pegawai sesuai dengan tugasnya dalam organisasi yang sesuai dengan standar yang telah ditentukan 
oleh organisasi tersebut. Disamping itu, kinerja tidak hanya segala sesuatu yang dikerjakan oleh pegawai, akan tetapi juga yang tidak dikerjakan oleh pegawai

\section{METODE PENELITIAN}

1. Tempat Penelitian

Penelitian ini dilaksanakan di Kantor Pusat Badan Amil Zakat Nasional BAZNAS (BAZIS) Provinsi DKI Jakarta yang beralamat di Graha Mental Spiritual Lantai 5, Jl. Awaludin II, RT.2/RW.17, Kebon Melati, Tanah Abang, Kota Jakarta Pusat, Daerah Khusus Ibukota Jakarta 10130

2. Waktu Penelitian

System proses penelitian ini di awali dengan kegiatan mengidentifdikasi permasalahan di tempat yang akan di gunakan sebagai lokasi penelitian, peerumusan masalah yang teridentifikasi pengumpulan dasar teori yang memperkuat landasan variable, penyusunan metode dalam pengumpulan data penyusunan instrument, sampai terlaksananya laporan penelitian ini yaitu bulan Maret 2021 sampai denagan Mei 2021.

3. Sifat Penelitian

Sifat penelitian yang di gunakan dalam skripsi ini adalah bersifat kuantitatif, yaitu hasil penelitian yang kemudian di olah dan di analisis untuk mengambil kesimpulanya, artinya penelitian yang di lakukan adalah penelitian yang menekan analisanya pada data-data angka, dengan metode ini akan di ketahui hubungan yang signifikan antara variable yang di teliti, sehingga menghasilkan kesimpulan yang akan memperjelas gambaran mengenai objek yang di teliti.

\section{Populasi dan Sampel}

\section{Populasi}

Populasi adalah wilayah generalisasi yang terdiri dari obyek/subyek dengan kualitas dan karakteristik tertentu yang ditetapkan oleh peneliti untuk dipelajari dan dibuat kesimpulannya. Populasi juga bukan sekedar jumlah yang ada pada obyek/subyek yang dipelajari, tetapi meliputi seluruh karakteristik/sifat yang dimiliki oleh subyek atau obyek itu. (Sugiyono 2017: 80). Populasi dalam penelitian ini adalah seluruh pegawai BAZNAS (BAZIS) Provinsi DKI Jakarta sejumlah 82 orang.

\section{Sampel}

Sampel adalah bagian dari jumlah dan karakteristik yang dimiliki oleh populasi tersebut. Bila populasi besar, dan peneliti tidak mungkin mempelajari semua yang ada pada populasi karena keterbatasan dana, tenaga dan waktu, maka peneliti dapat menggunakan sampel yang diambil dari populasi tersebut. (Sugiyono, 2017: 81).

Menurut Sugiyono (2017: 81) terdapat dua jenis teknik pengambilan sampel yang dapat digunakan yaitu teknik probability sampling dan teknik nonprobability sampling. Teknik probability sampling adalah teknik pengambilan sampel yang memberikan peluang yang sama bagi setiap unsur (anggota) populasi untuk dipilih menjadi anggota sampel. Sedangkan, Teknik nonprobability sampling adalah teknik pengambilan sampel yang tidak memberikan peluang/kesempatan sama bagi setiap unsur atau anggota populasi untuk dipilih menjadi sampel.

Dikarenakan jumlah populasi relatif kecil atau kurang dari 100 sehingga sampel yang diambil dalam penelitian ini ialah sampel jenuh, yang artinya semua populasi dijadikan sebagai sampel penelitian yakni sebanyak 82 orang pegawai pada BAZNAS (BAZIS) Provinsi DKI Jakarta.

\section{HASIL DAN PEMBAHASAN}

1. Pengaruh Penempatan (X1) Terhadap Kinerja Pegawai (Y) PadaBAZNAS

(BAZIS) Provinsi DKI Jakarta

Dari hasil kuesioner yang telah dibagikan kepada 82 responden 
diperoleh hasil bahwa penempatan pada BAZNAS (BAZIS) Provinsi DKI Jakarta sudah baik. Peneliti menyimpulkan berdasarkan hasil jawaban responden terhadap 10 pernyataan pada variabel penempatan diperoleh rata- rata tertinggi pada pernyataan nomor 7 yaitu sebesar 3,95 dengan kriteria baik dan rata - rata terendah adalah pada pernyataan nomor 1 yaitu sebesar 3,39 dengan kriteria kurang baik. Secara keseluruhan tanggapan responden terhadap variabel penempatan (X1) adalah baik yaitu dari jumlah rata - rata total sebesar 3,82 (termasuk dalam rentang skala 3,40 - 4,19 dengan kriteria baik).

Selanjutnya berdasarkan hasil analisis, diperoleh nilai persamaan regresi $Y=13,803+0,646 X 1$, nilai koefisien korelasi diperoleh sebesar 0,712 artinya kedua variabel mempunyai tingkat hubungan yang kuat. Nilai determinasi atau kontribusi pengaruhnya sebesar 0,506 atau sebesar $50,6 \%$ sedangkan sisanya sebesar $49,4 \%$ dipengaruhi oleh faktor lain. Uji hipotesis diperoleh nilai $t_{\text {hitung }}>t_{\text {tabel }}$ atau $(9,060>1,990)$. Dengan demikian Ho ditolak dan Ha diterima artinya terdapat pengaruh yang signifikan antara penempatan terhadap kinerja pegawai BAZNAS (BAZIS) Provinsi DKI Jakarta.

Hasil penelitian ini didukung oleh penelitian sebelumnya yang dilakukan oleh Heri Murtiyoko (2021) dengan judul Pengaruh Penempatan Kerja Terhadap Kinerja Karyawan Pada PT. Satria Putra Jaya di Jakarta. Hasil penelitiannya yaitu penempatan berpengaruh positif dan signifikan terhadap kinerja pegawai sebesar $60,8 \%$ sedangkan sisanya sebesar $39,2 \%$ dipengaruhi faktor lain. Uji hipotesis secara parsial diperoleh $t_{\text {hitung }}$ $>t_{\text {tabel }}$ atau $(10,278>1,995)$, sehingga Ho ditolak dan $\mathrm{Ha}$ diterima yang artinya terdapat pengaruh positif dan signifikan antara penempatan terhadap kinerja pegawai.

2. Pengaruh Lingkungan Kerja (X2) Terhadap Kinerja Pegawai (Y) Pada BAZNAS (BAZIS) Provinsi DKI Jakarta

Dari hasil kuesioner yang telah dibagikan kepada 82 responden diperoleh hasil bahwa lingkungan kerja pada BAZNAS (BAZIS) Provinsi DKI Jakarta sudah baik. Peneliti menyimpulkan berdasarkan hasil jawaban responden terhadap 10 pernyataan pada variabel lingkungan kerja diperoleh rata - rata tertinggi pada pernyataan nomor 10 yaitu sebesar 4,15 dengan kriteria baik dan rata - rata terendah adalah pada pernyataan nomor 1 yaitu sebesar 3,35 dengan kriteria kurang baik. Secara keseluruhan tanggapan responden terhadap variabel lingkungan kerja (X2) adalah baik yaitu dari jumlah rata - rata total sebesar 3,75 (termasuk dalam rentang skala 3,40 - 4,19 dengan kriteria baik).

Selanjutnya berdasarkan hasil pengujian, diperoleh nilai persamaan regresi $Y=15,831+0,604 \times 2$, nilai koefisien korelasi sebesar 0,619 artinya kedua variabel mempunyai tingkat hubungan yang kuat. Nilai determinasi atau kontribusi pengaruhnya sebesar 0,383 atau sebesar 38,3\% sedangkan sisanya sebesar $61,7 \%$ dipengaruhi oleh faktor lain. Uji hipotesis diperolehnilai $t_{\text {hitung }}>$ $t_{\text {tabel }}$ atau $(7,054>1,990)$. Dengan demikian Ho ditolak dan Haditerima artinya terdapat pengaruh yang signifikan antara lingkungan kerja terhadap kinerja pegawai BAZNAS (BAZIS) Provinsi DKI Jakarta.

Hasil penelitian ini didukung oleh penelitian sebelumnya yang dilakukan oleh Hendry Wijaya (2017) dengan judul Pengaruh Lingkungan Kerja Terhadap Kinerja Pegawai Pada Instansi Pemerintah Daerah Kabupaten Musi Banyuasin (Studi Kasus Dinas Pertambangan Dan 
Energi Kabupaten Musi Banyuasin). Dalam penelitiannya didapatkan hasil yaitu lingkungan kerja berpengaruh positif dan signifikan terhadap kinerja pegawai sebesar $46,2 \%$ dan 53,8\% dipengaruhi oleh faktor lain. Uji hipotesis secara parsial diperoleh $t_{\text {hitung }}$ $>t_{\text {tabel }}$ atau $(5,636>2,0262)$, sehingga Ho ditolak dan $\mathrm{Ha}$ diterima yang artinya terdapat pengaruh positif dan signifikan antara lingkungan kerja terhadap kinerja pegawai.

3. Pengaruh Penempatan (X1) dan Lingkungan Kerja (X2) Terhadap Kinerja Pegawai (Y) Pada BAZNAS (BAZIS) Provinsi DKI Jakarta

Dari hasil kuesioner yang telah dibagikan kepada 82 responden diperoleh hasil bahwa kinerja pegawai BAZNAS (BAZIS) Provinsi DKI Jakarta sudah baik. Peneliti menyimpulkan berdasarkan hasil jawaban responden terhadap 10 pernyataan pada variabel kinerja pegawai diperoleh rata - rata tertinggi pada pernyataan nomor 7 yaitu sebesar 3,95 dengan kriteria baik dan rata - rata terendah adalah pada pernyataan nomor 1 yaitusebesar 3,38 dengan kriteria kurang baik. Secara keseluruhan tanggapan responden terhadap variabel kinerja pegawai $(Y)$ adalah baik yaitu dari jumlah rata rata total sebesar 3,85 (termasuk dalam rentang skala 3,40 - 4,19 dengan kriteria baik).

Kemudian berdasarkan hasil penelitian, menunjukkan bahwa Penempatan (X1) dan Lingkungan kerja (X2) berpengaruh signifikan terhadap Kinerja Pegawai dengan diperoleh persamaan regresi $Y=8,835$ $+0,482 X 1+0,300 X 2$. Nilai koefisien korelasi atau tingkat hubungan antara variabel bebas dengan variabel terikat diperoleh sebesar 0,754 artinya memiliki hubungan yang kuat. Nilai koefisien determinasi atau kontribusi pengaruhnya secara simutan sebesar $56,8 \%$ sedangkan sisanya sebesar $43,2 \%$ dipengaruhi oleh faktor lain. Uji hipotesis diperoleh nilai $F_{\text {hitung }}>F_{\text {tabel }}$ atau $(51,977>2,720)$. Dengan demikian Ho ditolak dan Ha diterima. Artinya terdapat pengaruh yang signifikan secara simultan antara penempatan dan lingkungan kerja terhadap kinerja pegawai BAZNAS (BAZIS) Provinsi DKI Jakarta.

Hasil penelitian ini didukung oleh penelitian sebelumnya yang dilakukan oleh Faris Afif, dkk (2020) dengan judul Pengaruh Penempatan Kerja Dan Lingkungan Kerja Terhadap Kinerja Pegawai Pada Cv. Gema Insani Press Di Depok dengan hasil penelitian yaitu penempatan dan lingkungan kerja berpengaruh positif dan signifikan terhadap kinerja pegawai sebesar $56,3 \%$ sedangkan sisanya $43,7 \%$ dipengaruhi oleh faktor lain. Uji hipotesis secara simultan diperoleh $f_{\text {hitung }}>f_{\text {tabel }}$ atau $(62,438>3,09)$, sehingga hal ini menunjukkan bahwa terdapat pengaruh antara penempatan dan lingkungan kerja terhadap kinerja pegawai.

\section{KESIMPULAN DAN SARAN \\ Kesimpulan}

Berdasarkan hasil penelitian dan pembahasan hasil serta berpedoman pada tujuan penelitian,seperti yang di paparkan pada bab sebelumnya, maka dapat di tarik kesimpulan penelitian ini sebagai berikut:

1. Penempatan (X1) berpengaruh signifikan terhadap kinerja pegawai (Y) dengan persamaan regresi $\mathrm{Y}=$ $13,803+0,646 X_{1}$, nilai korelasi sebesar 0,712 artinya kedua variabel memiliki tingkat hubungan yang kuat. Nilai koefisien determinasi sebesar 50,6\%. Uji hipotesis diperoleh $t_{\text {hitung }}>t_{\text {tabel }}$ atau $(9,060>1,990)$. Dengan demikian $\mathrm{H}_{\mathrm{o}}$ ditolak dan $\mathrm{H}_{\mathrm{a}}$ diterima artinya terdapat pengaruh signifikan penempatan terhadap kinerja pegawai.

2. Lingkungan kerja (X2) berpengaruh signifikan terhadap kinerja pegawai $(Y)$ dengan persamaan regresi $Y=15,831$ $+0,604 X_{2}$ nilai korelasi sebesar 0,619 artinya kedua variabel memiliki tingkat hubungan yang kuat. Nilai 
koefisien determinasi sebesar 38,3\%. Uji hipotesis diperoleh $t_{\text {hitung }}>t_{\text {tabel }}$ atau $(7,054>1,990)$. Dengan demikian $\mathrm{H}_{\mathrm{o}}$ ditolak dan $\mathrm{H}_{\mathrm{a}}$ diterima artinya terdapat pengaruh signifikan lingkungan kerja terhadap kinerja pegawai.

3. Penempatan (X1) dan lingkungan kerja (X2) berpengaruh signifikan terhadap kinerja pegawai $(\mathrm{Y})$ dengan persamaan regresi $\mathrm{Y}=8,835+0,482 \mathrm{X}_{1}+0,300 \mathrm{X}_{2}$. Nilai korelasi sebesar 0,754 artinya variabel bebas dengan variabel terikat memiliki tingkat hubungan yang kuat. Nilai koefisien determinasi sebesar $56,8 \%$ sedangkan sisanya sebesar $43,2 \%$ dipengaruhi faktor lain. Uji hipotesis diperoleh nilai $F_{\text {hitung }}>F_{\text {tabel }}$ atau $(51,977>2,720)$. Dengan demikian $\mathrm{H}_{\mathrm{o}}$ ditolak dan $\mathrm{H}_{\mathrm{a}}$ diterima artinya terdapat pengaruh signifikan secara simultan penempatan dan lingkungan kerja terhadap kinerja pegawai.

\section{Saran}

Berdasarkan hasil penelitian pembahasan dan kesimpulan di atas, penulis dapat memberikan saran yang berhubungan dengan kompensasi dan disiplin kerja terhadap kinerja kariyawan, antara lain sebagai berikut:

1. Penempatan pernyataan yang paling lemah adalah nomor 1 yaitu "saya ditempatkan di instansi ini sudah sesuai dengan latar belakang pendidikan yang saya miliki" dimana hanya mencapai score sebesar 3,39. Untuk lebih baik lagi, BAZNAS (BAZIS) Provinsi DKI Jakarta harus lebih memperhatikan serta mengoptimalkan dalam menempatkan pegawainya, karena dengan penempatan yang tepat maka akan membantu organisasi untuk mencapai tujuannya. Khususnya lebih mempertimbangkan dan mengoptimalkan lagi penempatan pegawai agar sesuai dengan pendidikan yang dimiliki oleh pegawai tersebut.
2. Lingkungan kerja pernyataan yang paling lemah adalah nomor 1 yaitu "pencahayaan yang ada di tempat kerja sudah membantu saya dalam menyelesaikan pekerjaan" dimana hanya mencapai score sebesar 3,35. Untuk lebih baik lagi, BAZNAS (BAZIS) Provinsi DKI Jakarta harus lebih memperhatikan kondisi lingkungan kerja kantor terutama yang berkaitan dengan pencahayaan di ruang kerja. Pencahayaan yang terlalu redup ataupun terlalu terang tentu akan membuat pegawai kurang nyaman dalambekerja sehingga akan menghambat pekerjaan, maka dari itu pencahayaan perlu diperhatikan agar dapat mendukung kinerja pegawai yang lebih baiklagi.

3. Kinerja pegawai pernyataan yang paling lemah adalah nomor 1 yaitu "kuantitas kerja saya sesuai dengan standar kerja / target yang ditentukan" dimana hanya mencapai score sebesar 3,38. Untuk lebih baik lagi, pegawai BAZNAS (BAZIS) Provinsi DKI Jakarta harus selalu berpedoman pada standar kerja yang ada, memperhatikan dan berusaha untuk mencapai target organisasi. Selain itu, BAZNAS (BAZIS) Provinsi DKI Jakarta juga diharapkan mampu untuk memenuhi kebutuhan pegawai dalam hal pekerjaan karena jika kebutuhan pegawai terpenuhi maka pegawai akan dengan senang hati melakukan semua pekerjaan yang telah ditargetkan oleh organisasi dan hasil pekerjaannya menjadi maksimal.

\section{DAFTAR PUSTAKA}

Afif, F., Chairunnisa, C., \& Habibi, P. (2020). Pengaruh Penempatan Kerja Dan Lingkungan Kerja Terhadap Kinerja Karyawan Pada CV. Gema Insani Press Di Depok. Jurnal Dimensi, 9(1), 163-177.

Aldy, H. L. N. (2020). Pengaruh Penempatan Kerja Terhadap Kinerja Karyawan Pada Yayasan Hanifa Islamic School. Jurnal Ekonomi 
Efektif, 2(2).

Algifari. (2015). Analisis Regresi untuk Bisnis dan Ekonomi. Yogyakarta: BPFE.

Arikunto, S. (2015). Prosedur Penelitian Suatu Pendekatan Praktek. Jakarta: Rineka Cipta.

Bandung: CV Alfabeta.

Bangun, W. (2012). Manajemen Sumber Daya Manusia . Jakarta: PT Gelora Aksara Pratama.

Bone, Y., Aneta, Y., \& Bokingo, A. H. (2018). Pengaruh Penempatan kerja Terhadap Kinerja Pegawai Di Badan Perencanaan Penelitian dan Pengembangan Daerah Provinsi Gorontalo. JAMBURA: Jurnal Ilmiah Manajemen dan Bisnis, 1(1), 19-27.

Budianto, A. A. T., \& Katini, A. (2017). Pengaruh lingkungan kerja terhadap kinerja pegawai pada PT Perusahaan Gas Negara (PERSERO) Tbk SBU Distribusi wilayah I Jakarta. KREATIF: Jurnal Ilmiah Prodi Manajemen Universitas Pamulang, 3(1)

Ghozali, I. (2017). Aplikasi Analisis Multivariate dengan Program SPSS Edisi Kelima. Semarang: Badan Penerbit Undip.

Hasibuan, M. S. (2012). Manajemen Sumber Daya Manusia. Jakarta: Bumi Aksara.

Hasibuan, M. S. (2013). Manajemen Sumber Daya Manusia Edisi Revisi Cetakanke Enam. Jakarta: Bumi Aksara.

Hasibuan, M. S. (2017). Manajemen Sumber Daya Manusia Edisi Revisi. Jakarta: Bumi Aksara.

Hermawati, R., et al. (2020). The Effect of Trilogy Leadership Style and Organization Culture on School Performance: Evidence form Indonesian Senior High School. PalArch's Journal of Archaeology of Egypt/Egyptology, 17(6), 8512-8537.

Kadarisman. (2012). Manajemen Pengembangan Sumber Daya Manusia. Jakarta:Rajawali Pers.

Karlina, D. (2018). Hubungan Komunikasi Interpersonal, Disiplin Kerja Dan
Lingkungan Kerja Terhadap Kinerja Pegawai Kantor Pusat LPP TVRI. JENIUS (Jurnal Ilmiah Manajemen Sumber Daya Manusia), 1(2).

Komarudin, K. (2018). Pengaruh Lingkungan Kerja Terhadap Kinerja Karyawan Pada PT. Pos Indonesia Depok. JENIUS (Jurnal Ilmiah Manajemen Sumber Daya Manusia), 1(3).

Mangkunegara, A. P. (2013). Manajemen Sumber Daya Manusia Organisasi Cetakan Kedua Belas. Bandung: PT Remaja Rosdakarya.

Maulana, M. K. (2019). Pengaruh Penempatan Dan Lingkungan Kerja Terhadap Prestasi Kerja Karyawan Pt. Jelajah Laut Nusantara Jakarta. Jurnal Ekonomi dan Industri, 20(1).

Moeheriono. (2012). Pengukuran Kinerja Berbasis Kompetensi. Jakarta: Raja Grafindo Persada.

Mogi, A. (2018). Pengaruh Kompetensi Guru, Motivasi Guru Dan Lingkungan Sekolah Terhadap Hasil Belajar Siswa Sma Tunas Indonesia Bintaro. JENIUS (Jurnal Ilmiah Manajemen Sumber Daya Manusia), 1(2).

Murtiyoko, H. (2021). Pengaruh Penempatan Kerja Terhadap Kinerja Karyawan Pada Pt. Satria Putra Jaya Di Jakarta. Jurnal Ekonomi Efektif, 3(2).

Nitiseminoto, A. S. (2012). Manajemen Personalia Edisi Kedua Belas. Jakarta: Ghalia Indonesia.

Nuraini. (2013). Manajemen Sumber Daya Manusia. Pekanbaru: Yayasan Ainisyam.

Nurjaman, K. (2014). Manajemen Personalia. Bandung: Pustaka Setia.

Pawar, A., et al. (2020). Organizational Servant Leadership. International Journal of Educational Administration, Management, and Leadership, 63-76.

Rivai, V. (2011). Manajemen Sumber Daya Manusia untuk Perusahaan dari Teorike Praktik. Jakarta: Raja Grafindo Persada. 
Rivai, V. (2014). Manajemen Sumber Daya Manusia untuk Perusahaan dari Teorike Praktik . Jakarta: Raja Grafindo Persada.

Romdonih, F. (2018). Pengaruh Lingkungan Kerja Terhadap Kepuasan Kerja Pegawai Pada Pusat Pendidikan Dan Pelatihan (Pusdiklat) Perdagangan Depok. JENIUS (Jurnal Ilmiah Manajemen Sumber Daya Manusia), 1(2).

Rondo, D. W., Koleangan, R. A., \& Tawas, H. (2018). Pengaruh Kepribadian, Lingkungan Kerja Dan Penempatan Kerja Terhadap Kinerja Karyawan (Pada Pt. Bpr Prisma Dana Manado). Jurnal EMBA: Jurnal Riset Ekonomi, Manajemen, Bisnis dan Akuntansi, 6(4).

Rudianto, A. B., \& Juniarti, A. T. (2018). Pengaruh Disiplin Kerja dan Penempatan Pegawai Terhadap Semangat Kerja Pegawai di PT. Taspen (Persero) KCU Bandung (Doctoral dissertation, Perpustakaan Fakultas Ekonomi dan Bisnis Unpas Bandung).

Sazly, S., \& Permana, D. (2020). Pengaruh Lingkungan Kerja Terhadap Kinerja Pegawai Pada Kantor Kecamatan Teluknaga Kabupaten Tangerang. JurnalPerspektif, 18(2), 209-217.

Sedarmayanti. (2011). Manajemen Sumber Daya Manusia, Reformasi Birokrasi dan Manajemen Pegawai Negeri Sipil Cetakan Ketiga. Bandung: PT Refika Aditama.

Sudaryo, Y., Ariwibowo, A. \& Sofiati, N. A. (2018). Manajemen Sumber Daya Manusia Kompensasi Tidak Langsung dan Lingkungan Kerja Fisik. Yogyakarta : ANDI.

Sudjana. (2013). Metode Statistik . Jakarta: Rineka Cipta.

Sugiyono. (2014). Metode Penelitian: Pendekatan Kuantitatif, Kualitatif dan $R \mathcal{E D}$.

Sugiyono. (2017). Metode Penelitian Kuantitatif, Kualitatif dan RED Cetakan Kedua Puluh Enam. Bandung: CV Alfabeta.
Sugiyono. (2018). Metode Penelitian Kombinasi (Mixed Methods). Bandung: CV Alfabeta.

Sulfiyah, S. (2015). Pengaruh Penempatan Pegawai Dan Lingkungan Kerja Terhadap Kinerja Pegawai Pada Dinas Kelautan Dan Perikanan Provinsi Banten. Sains Manajemen, 1(1).

Sunyoto. (2012). Teori, Kuesioner dan Analisis Data Sumber Daya Manusia. Yogyakarta: CAPS.

Suryani, N. L. (2018). Pengaruh Motivasi Terhadap Prestasi Pegawai Pada Pusdiklat Tenaga Administrasi Kementerian Agama RI CiputatTangerang. JENIUS (Jurnal Ilmiah Manajemen Sumber Daya Manusia), 1(3).

Sutarno. (2012). Serba-Serbi Manajemen Bisnis Cetakan Satu Edisi Satu. Yogyakarta: Graha Ilmu.

Sutrisno, E. (2017). Manajemen Sumber Daya Manusia. Jakarta: Kencana

Terry, G. R. (2015). Dasar - Dasar Manajemen Edisi Bahasa Indonesia . Jakarta:Kencana.

Widodo, S. E. (2015). Manajemen Pengembangan Sumber Daya Manusia. Yogyakarta: Pustaka Pelajar.

Wijaya, H., \& Susanty, E. (2017). Pengaruh lingkungan kerja terhadap kinerja pegawai pada instansi pemerintah daerah kabupaten musi banyuasin (studi kasus dinas pertambangan dan energi kabupaten musi banyuasin). JurnalEcoment Global: Kajian Bisnis dan Manajemen, 2(1), 40-50.

Wilandari, D. F., et al. (2021). Pengaruh Penilaian Kerja Terhadap Kinerja Karyawan Pada PT. Jaya Mandiri Rekabuana di Cilandak. Jurnal Ekonomi Efektif, 3(2).

Yuniarsih, T. \& Suwatno. (2013). Manajemen Sumber Daya Manusia. Yogyakarta: CV Alfabeta. 